\title{
Glyphosate Resistance in Perennial Ryegrass (Lolium perenne L.) is Associated with a Fitness Penalty
}

\author{
Marcos Yanniccari, Martín Vila-Aiub, Carolina Istilart, Horacio Acciaresi, and Ana M. Castro*
}

The net selection effect of herbicides on herbicide-resistance traits in weeds is conditioned by the fitness benefits and costs associated with resistance alleles. Fitness costs play an important evolutionary role preventing the fixation of adaptive alleles and contributing to the maintenance of genetic polymorphisms within populations. Glyphosate is widely used in world agriculture, which has led to the evolution of widespread glyphosate resistance in many weed species. The fitness of glyphosate-resistant and -susceptible perennial ryegrass plants selected from within a single population were studied in two field experiments conducted during 2011 and 2012 under different soil water availability. Glyphosate-resistant plants showed a reduction in height of 12 and 16\%, leaf blade area of 16 and $33 \%$, shoot biomass of 45 and 55\%, seed number of 33 and $53 \%$, and total seed mass of 16 and 5\% compared to glyphosate-susceptible plants in 2011 and 2012, respectively. The reduction in seed number per plant resulted in a $40 \%$ fitness cost associated with the glyphosate-resistance trait in perennial ryegrass. Fitness costs of glyphosate-resistant plants were expressed under both conditions of water availability. These results could be useful for designing management strategies and exploiting the reduced glyphosate-resistant perennial ryegrass fitness in the absence of glyphosate selection.

Nomenclature: Glyphosate; perennial ryegrass, Lolium perenne L., LOLPE.

Key words: Fitness trait, genetic background, plant competition, resistance evolution.

Continuous herbicide selection over genetically diverse plant populations often results in herbicideresistance evolution (Powles and $\mathrm{Yu}$ 2010). The rate of this evolutionary process results from the opposing benefit and cost effects associated with the adaptive alleles (Baucom and Mauricio 2004). The benefits of resistance alleles are clear, as they endow survival and reproduction under herbicide selection, with the magnitude of the benefit a function of the level of protection conferred to the treated plants. However, these benefits may be offset in herbicide-free environments because of the expression of negative pleiotropic effects on fitness (i.e., fitness costs) (Bergelson and Purrington 1996; Roux et al. 2004; Tardif et al. 2006; Vila-Aiub et al. 2005b).

\footnotetext{
DOI: 10.1614/WS-D-15-00065.1

${ }^{*}$ First and fifth authors: Researchers, Plant Physiology Institute (Consejo Nacional de Investigaciones Científicas y Técnicas, Universidad Nacional de La Plata), La Plata (1900), Argentina; second author: Researcher, Agricultural Plant Physiology and Ecology Research Institute (Consejo Nacional de Investigaciones Científicas y Técnicas, Universidad de Buenos Aires), Buenos Aires (1417), Argentina, and School of Plant Biology, Institute of Agriculture, University of Western Australia; third author: Researcher, Chacra Experimental Integrada Barrow (MAAINTA), Tres Arroyos (7500), Argentina; fourth author: Researcher, Comisión de Investigaciones Científicas Provincia de Buenos Aires \& INTA, Pergamino (2700), Argentina. Corresponding author’s E-mail: marcosyanniccari@conicet.gov.ar
}

Fitness costs play an important evolutionary role in preventing the fixation of adaptive alleles and contributing to the maintenance of genetic polymorphisms within populations (Antonovics and Thrall 1994). Herbicide-resistance traits are rare in weed populations prior to herbicide selection, and fitness costs, together with random genetic drift, are the driving ecological factors associated with their net frequency in agroecosystems (Preston and Powles 2002). Fitness costs associated with herbicideresistance alleles are evident, but not universal, among plant species (Vila-Aiub et al. 2009). There are inherent difficulties in measuring the expression and magnitude of fitness costs, and therefore the control of genetic background is essential to ascribe costs unequivocally to herbicide-resistance alleles (Vila-Aiub et al. 2011).

The adoption of glyphosate-resistant transgenic crops, mainly in the Americas, has resulted in glyphosate becoming the most widely used herbicide in the world. This has inevitably increased the selection intensity for glyphosate-resistance traits in agroecosystems (Vila-Aiub et al. 2008). Since the first report of glyphosate resistance, the evolution of glyphosate-resistant weed populations has rapidly escalated (Duke and Powles 2008; Powles et al. 1998). However, to date there is little understanding of the fitness cost associated with glyphosateresistance genes (Vila-Aiub et al. 2009). A recent 
report has documented a reduction in the glyphosate-resistance phenotypic frequency over several generations in segregating rigid ryegrass (Lolium rigidum Gaudin) populations exhibiting glyphosate vacuolar sequestration as the glyphosate-resistance mechanism (Ge et al. 2012; Preston et al. 2009). However, the particular fitness traits responsible for the reversion of the glyphosate-resistance frequency in these populations have not been identified.

The expression of fitness costs associated with herbicide-resistance alleles is not universal (Vila-Aiub et al. 2009). The expression of fitness costs has been shown to depend on the particular herbicideresistance gene (Vila-Aiub et al. 2005a) and allele (Ashigh and Tardif 2007; Menchari et al. 2008; Purrington and Bergelson 1999; Vila-Aiub et al. 2015a; Yu et al. 2010), the dominance of the fitness cost (Roux et al. 2004), the genetic background (Paris et al. 2008), and the abiotic and biotic environmental conditions. Fitness costs associated with glyphosate resistance have been reported to vary from small to negligible. Associated with a glyphosatereduced translocation trait (Preston and Wakelin 2008), Pedersen et al. (2007) reported a reduction (4 to $18 \%$ ) in seed number associated with resistant rigid ryegrassplants when subjected to no or low competition from wheat. Recent results from $\mathrm{Yu}$ et al. (2015) suggest that a significant resistance cost would be associated with a double target-site mutation in the 5-enolpyruvyl-shikimate-3-phosphate synthase (EPSPS) gene in glyphosate-resistant goosegrass [Eleusine indica (L.) Gaertn.]. However, no evidence of fitness costs has been found in glyphosate-resistant Palmer amaranth (Amaranthus palmeri S. Wats.) exhibiting higher amplification of the EPSPS gene (Giacomini et al. 2014; Vila-Aiub et al. 2014).

Cytochrome $\mathrm{P} 450$ enhanced metabolism and particular target-site ACCase gene mutations (Asp-2078Gly) are associated with the expression of fitness costs in rigid ryegrass (Vila-Aiub et al. 2005a,b, 2009). However, rigid ryegrass plants carrying ALSresistance alleles or other particular ACCase mutations (Ile-1781-Leu) do not express any reduction in fitness traits (Vila-Aiub et al. 2015a; Yu et al. 2010).

The assessment of fitness costs enables a better understanding and prediction of herbicide-resistance evolution in weed populations, and therefore, its estimation has a role in developing better resistancemanagement practices (Jasieniuk et al. 1996; Jordan et al. 1999; Menchari et al. 2008; Vila-Aiub et al. 2009). Given the important value of glyphosate in current agriculture worldwide and the rapid widespread glyphosate-resistance evolution in many weed species, it is significant to quantify the effect of glyphosate-resistance traits on plant fitness.

Lolium species commonly occur as weeds of cereal crops (Charmet et al. 1996). In Argentina, naturalized populations of perennial ryegrass are often found in disturbed plant communities throughout the country, and are present in grasslands of the Pampas region (Yanniccari and Acciaresi 2013). Perennial ryegrass is allogamous, allowing some degree of self-pollination (Yanniccari et al. 2015), and each plant can produce up to 12,000 seeds (Lodovichi and Yanniccari 2015). Both factors play a key role in herbicide-resistance evolution (Powles and Yu 2010).

Glyphosate resistance in perennial ryegrass has been recently identified for the first time in agroecosystems (Yanniccari et al. 2012a). In this population, a 10.8-fold greater dose of glyphosate was necessary to match the control efficiency on the susceptible one (Yanniccari et al. 2012a). Results from preliminary experiments have shown that glyphosate resistance in this population is due to higher EPSPS activity (M. Yanniccari, unpublished observation) and controlled by a single locus with incomplete dominance in which maternal effects are unlikely to play a major role (Yanniccari et al. 2015). The aim of the present study was to assess and quantify the effect of glyphosate resistance on growth traits and reproductive fitness in glyphosate-free environments.

\section{Materials and Methods}

Plant Material and Genetic Background Control. Perennial ryegrass seeds from a large segregating glyphosate-resistant population were collected in a field of the south of Buenos Aires province $\left(37^{\circ} \mathrm{S}, 62^{\circ} \mathrm{W}\right)$ in 2009. In this area, perennial ryegrass is found over an extended area (8,000 ha) in which no landscape boundaries for pollen exchange among plants of this cross-pollinated species are evident. The fields had a history of 12 yr under no-tillage agriculture, with weed control based on three applications of glyphosate per year at doses ranging from 360 to $720 \mathrm{~g} \mathrm{ae} \mathrm{ha}^{-1}$ (Yanniccari et al. 2012a). One hundred field-collected seeds from 50 randomly chosen plants were germinated in Petri dishes containing filter paper with distilled water in a growth chamber with $75 \mu \mathrm{mol} \mathrm{m} \mathrm{m}^{-2} \mathrm{~s}^{-1}$ of photosynthetically active radiation, in a regime of $12 / 12 \mathrm{~h}$ of light/darkness and temperatures of $25 \mathrm{C} / 15 \mathrm{C}$ day/night. After $7 \mathrm{~d}$, each seedling was transferred to a pot of $250 \mathrm{~cm}^{3}$ filled with soil. The plants were grown in 
a greenhouse and pots were subirrigated daily to field capacity. Fertilizer $\left(12: 10: 20, \quad\right.$ Nitrofoska $^{\circledR}$, Compo Argentina) $\left(2 \mathrm{~g} \mathrm{~L}^{-1}\right)$ was added every $15 \mathrm{~d}$.

Plants were grown for $8 \mathrm{wk}$ and vegetative clones of individual plants were propagated by tiller partition in order to obtain four ramets per plant. When individual ramets developed three to four tillers, each one was treated with $0,500,1,000$, or $2,000 \mathrm{~g} \mathrm{ha}^{-1}$ glyphosate (isopropylamine salt of glyphosate, Roundup ${ }^{\circledR}, 360 \mathrm{~g} \mathrm{~L}^{-1}$, Monsanto Argentina), with the use of a backpack sprayer equipped with flat-fan nozzles (Teejet ${ }^{\circledR} 11002$ ) and calibrated to deliver $150 \mathrm{~L} \mathrm{ha}^{-1}$. At $21 \mathrm{~d}$ postapplication, plants were characterized as glyphosate susceptible (with no survivors at $500 \mathrm{~g} \mathrm{ha}^{-1}$ and higher doses) or glyphosate resistant (surviving plants at 2,000 $\mathrm{g} \mathrm{ha}^{-1}$ and lower doses). These contrasting phenotypes were expected to be the homozygous $(R R)$ glyphosate-susceptible and -resistant $\left(R^{\prime} R^{\prime}\right)$ genotypes, respectively (Yanniccari et al. 2015). Plants with intermediate glyphosate resistance (i.e., plants surviving at 500 or $1,000 \mathrm{~g} \mathrm{ha}^{-1}$ but not at higher rates, likely corresponding to heterozygous genotype $R R$ ') were discarded and not included in this study. Glyphosate-untreated susceptible and resistant clones were used for the field experiments. This protocol was chosen to obtain ecologically contrasting phenotypes sharing a common genetic background (Vila-Aiub et al. 2011).

Field Experiments. Field experiments were conducted in La Plata, Argentina $\left(34^{\circ} \mathrm{S}, 58^{\circ} \mathrm{W}\right)$ under field conditions during June to December 2011 and repeated during the same months in 2012. In each year, 18 glyphosate-resistant and 18 susceptible plants at five- to six-tiller stage were planted in winter and grown in experimental plots with plants spaced at $30 \mathrm{~cm}$ in a square planting pattern in a completely randomized design with 18 replicates per phenotype.

The soil was a typical Argiudoll with the following characteristics in the upper $25 \mathrm{~cm}$ : loamy, $4.2 \%$ organic matter, $0.24 \%$ N, 23 ppm P (Bray Kurtz), and $\mathrm{pH}$ of 6.8. The field history was 3 and $4 \mathrm{yr}$ of pastures in 2011 and 2012, respectively (no herbicide was applied in the pasture). Prior to the experiments, soil was tilled with the use of a motocultor (ER-75, Kubota, Osaka, Japan). In the 2011 experiment, irrigation (35 mm weekly, with a total of $840 \mathrm{~mm}$ in the growing season) was used to complement rainfall (303 $\mathrm{mm}$ in the growing season). In the 2012 experiment, glyphosate-resistant and -susceptible plants competed under rain-fed conditions
(543 $\mathrm{mm}$ in the growing season). Manual weeding was performed weekly in both experiments.

Assessment of Plant Fitness Traits. Growth habit (prostrate or erect); plant height (from the tiller base to the apex of most distant organ-leaf or spike) at 60,120, and $150 \mathrm{~d}$ after planting (DAP); leaf blade area $(n=10$ per plant) at heading stage (following the nondestructive method of Pandey and Singh 2011); shoot biomass at maturity stage; seed mass (i.e., 1,000 seed weight with $12 \%$ of humidity) and number; and harvest index (seed mass to total aboveground biomass ratio) per plant were measured in both years. Harvested plants were dried in a circulating air oven at $60 \mathrm{C}$ to constant moisture content. In the 2012 experiment, the number of spikes per plant, spikelets per spike, and seeds per spikelets were recorded. The numbers of days required to visible first node of stem, heading stage, and harvest maturity were recorded on a weekly basis.

The magnitude (\%) of the fitness cost associated with glyphosate resistance was estimated as ([1(resistant fitness/susceptible fitness)] $\times 100)$ based on the number of seeds produced per plant (Maynard Smith 1998).

Glyphosate-Resistance Profile in the Selected S and R Phenotypes: Progeny Bioassay. Glyphosateresistance assessment of the selected discrete glyphosate-resistant and -susceptible plants was conducted by examining the resistance profile of their progeny. In a greenhouse, clones of the selected plants were grown in 3-L pots with soil. In order to ensure cross pollination within resistant or susceptible phenotypes, the glyphosate-resistant and -susceptible plants were isolated in pollen-proof enclosures at the reproductive stage. At maturity, seeds were collected and stored under laboratory conditions (room temperature, ranging between 20 and $25 \mathrm{C}$ ). Glyphosate resistance was estimated by measuring coleoptile growth of 50 seeds per treatment incubated in Petri dishes containing filter paper and $10 \mathrm{ml}$ of 0,10 , $20,40,80,160,320$, and $640 \mathrm{mg}$ glyphosate $\mathrm{L}^{-1}$ (Yanniccari et al. 2012a).

Seeds were incubated in a growth chamber for $7 \mathrm{~d}$ with $75 \mathrm{mmol} \mathrm{m} \mathrm{m}^{-2}$ of photosynthetically active radiation, 12-h photoperiod, and $25 \mathrm{C} / 15 \mathrm{C}$ day/ night fluctuating temperature, with three replicates per herbicide treatment. This experiment was repeated twice. 


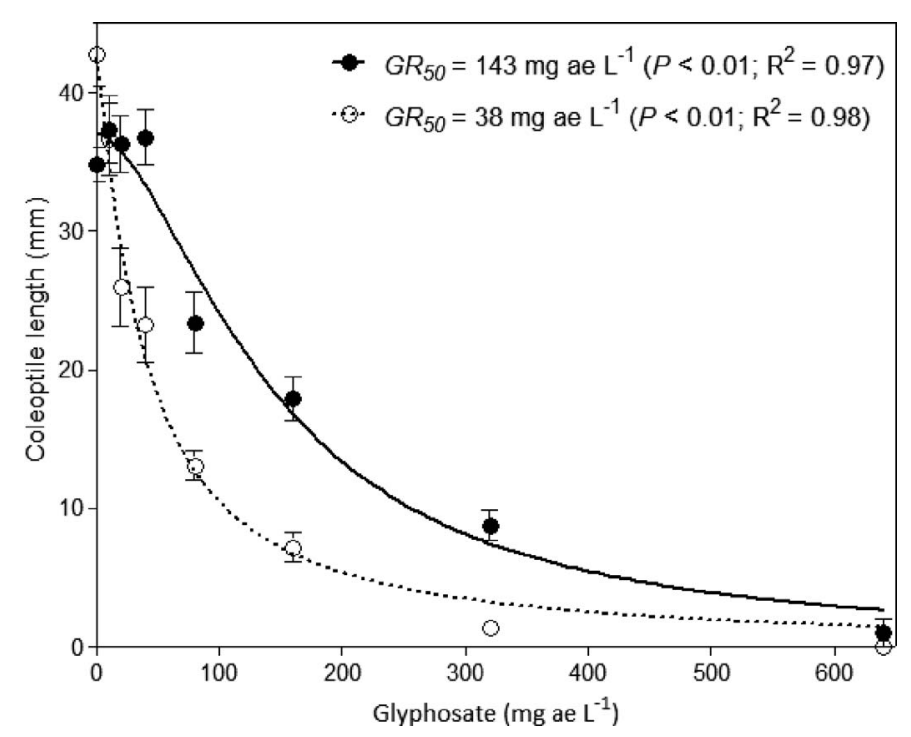

Figure 1. Coleoptile length $(\mathrm{mm})$ in glyphosate-resistant $(\bullet)$ and -susceptible (0) Perennial ryegrass seedlings $7 \mathrm{~d}$ after seed germination in response to increasing glyphosate rates. Lines are predicted values derived from nonlinear regression analysis $(\mathrm{P}$ value for model significance and $R^{2}$ are shown). Symbols denote mean $(n=3) \pm$ standard error of the mean.

Statistical Analysis. Coleoptile length was analyzed by nonlinear log-logistic regression as described by Streibig et al. (1993):

$$
y=\frac{C+(D-C)}{1+\left(\frac{x}{G R_{50}}\right)^{b}}
$$

where $y$ is the coleoptile length at the herbicide concentration $x, C$ is the lower asymptote, $D$ is the upper asymptote, $b$ is the slope of the line, and $\mathrm{GR}_{50}$ is the glyphosate concentration required to inhibit $50 \%$ of coleoptile growth. To assess the accuracy of the model, $F$ test for model significance, residual variance analysis and coefficient of determination $\left(R^{2}\right)$ were estimated. The independence of the models for progenies from both resistant and susceptible phenotypes was evaluated with the use of an $F$ test. $\mathrm{GR}_{50}$ parameters of both data sets were compared.

A chi-square test $\left(\chi^{2}\right)$ for independence of glyphosate sensitivity and growth habit was performed. All other data were analyzed by one-way or multifactorial analysis of variance (ANOVA) according to the number of sources of variation considered: phenotype (glyphosate resistant and susceptible), year (2011 and 2012), DAP (60, 120, and 150), and their interactions. Residual plots indicated that the variances were normally distributed and Bartlett's test was used to determine variance homogeneity. Means were compared with the use of Fisher's LSD test $(\mathrm{P}<0.05)$.

\section{Results and Discussion}

In the initial selection tests with the field-collected perennial ryegrass population, a total of 90 and 93 plants were characterized according to their response to glyphosate sensitivity in the 2011 and 2012 experiments, respectively. About $20 \%$ of the plants survived at $2,000 \mathrm{~g} \mathrm{ha}^{-1}, 30 \%$ of the individuals were controlled at $500 \mathrm{~g} \mathrm{ha}^{-1}$, and the remainder of the plants showed intermediate glyphosate resistance. These results are in agreement with those reported previously from this perennial ryegrass population (Yanniccari et al. 2012a). The glyphosate-susceptible and -resistant plants identified from within the perennial ryegrass population served as the phenotypic lines for the fitness studies.

Glyphosate-Resistance Bioassay. A significant difference in coleoptile length was evident between the glyphosate-resistant and -susceptible germinated seeds in the presence of glyphosate. Coleoptile growth in the susceptible seeds was more inhibited by glyphosate compared to that of resistant seeds (Figure 1). Estimated glyphosate concentrations to inhibit $50 \%$ coleoptile growth $\left(\mathrm{GR}_{50}\right)$ for the susceptible and resistant phenotypes were 38 and 143 $\mathrm{mg} \mathrm{L}^{-1}$, respectively (Figure 1 ), making the glyphosate-resistant phenotype within the population fourfold resistant to glyphosate.

Phenology and Growth Habit. No significant differences were recorded in the length of vegetative and reproductive stages between the glyphosateresistant and -susceptible plants $(\mathrm{P}=0.79)$. On average, the reproductive period started at $60 \mathrm{DAP}$. Similarly, the number of days from planting to spike emergence (i.e., heading) stage showed no differences between phenotypes $(\mathrm{P}=0.39)$ (Table 1). These results were similar in both years $(\mathrm{P}=0.25)$. Glyphosate-resistant and -susceptible phenotypes showed both prostrate and erect growth habits being equally represented $(P=0.65)$, within each phenotype at 55 and $45 \%$ erect and prostrate plants, respectively.

Fitness Traits: Vegetative Growth. Significant interactions of phenotype $* D A P$ and year $* D A P$ were found for plant height of glyphosate-resistant and -susceptible phenotype (Table 2). This indicates that plant height was different between phenotypes depending on the elapsed days after planting and differences in height were also found between years regardless of the phenotype (Table 2 ). This differential plant height between phenotypes was evident in 
Table 1. Phenological development of glyphosate-resistant and -susceptible perennial ryegrass phenotypes. $^{\text {a }}$

\begin{tabular}{lccc}
\hline Phenotype & Days to first node of stem visible & Days to heading stage & Days to harvest maturity \\
\hline Susceptible & $60.0 \pm 1.8$ & $132.0 \pm 1.2$ & $196.4 \pm 1.6$ \\
Resistant & $60.8 \pm 2.4$ & $133.8 \pm 1.7$ & $194.2 \pm 2.1$ \\
\hline
\end{tabular}

${ }^{a}$ Days were counted from transplanting until the corresponding developmental stage. Means values of the 2011 and 2012 experiments \pm standard error of the mean are shown $(n=36)$.

both 2011 and 2012 (Table 2), with individuals from the glyphosate-resistant phenotype being shorter ( $14 \%$ on average), compared to plants from the glyphosate-susceptible phenotype (Figure 2). Differences in plant height were apparent during the reproductive stage (120 and 150 DAP) when glyphosate-resistant plants were 11.8 and $10.7 \mathrm{~cm}$ shorter than susceptible plants in 2011 and 2012, respectively (Figure 2).

Leaf blade area was significantly different $(\mathrm{P}<$ 0.001 ) between biotypes in both years and between years with leaf blade area larger in 2011 than 2012 (Table 2, Figure 3A), but showed no significant interaction of phenotype $*$ year $(\mathrm{P}=0.83)$. Plants of the glyphosate-resistant phenotype showed, on average, a $24.5 \%$ lower leaf blade area compared to plants of the susceptible phenotype (Figure 3A).
The results of this study show that despite no apparent variations in phenological traits and growth habits between the glyphosate-resistant and -susceptible perennial ryegrass phenotypes, resistant individuals express differences in fitness traits. At the reproductive stage, individuals of the resistant phenotype were consistently shorter than plants of the susceptible phenotype. This differential plant height is likely to influence the amount of light intercepted by plants, which has important implications for the potential competitive ability (Falster and Westoby, 2003). Plants with a greater leaf area index concentrated in the upper canopy have also been shown to display a competitive advantage for light (Grahan et al. 1998).

Total shoot biomass produced per plant was different between phenotypes $(\mathrm{P}<0.001)$. Although year had a significant effect on the production of

Table 2. Summary of ANOVA: mean-square (MS), degrees of freedom (df), and probability values (P) for the effect of Lolium perenne phenotype, ${ }^{\mathrm{a}}$ year of experiment, ${ }^{\mathrm{b}}$ days after planting (DAP), ${ }^{\mathrm{c}}$ and their interaction on vegetative and reproductive growth parameters.

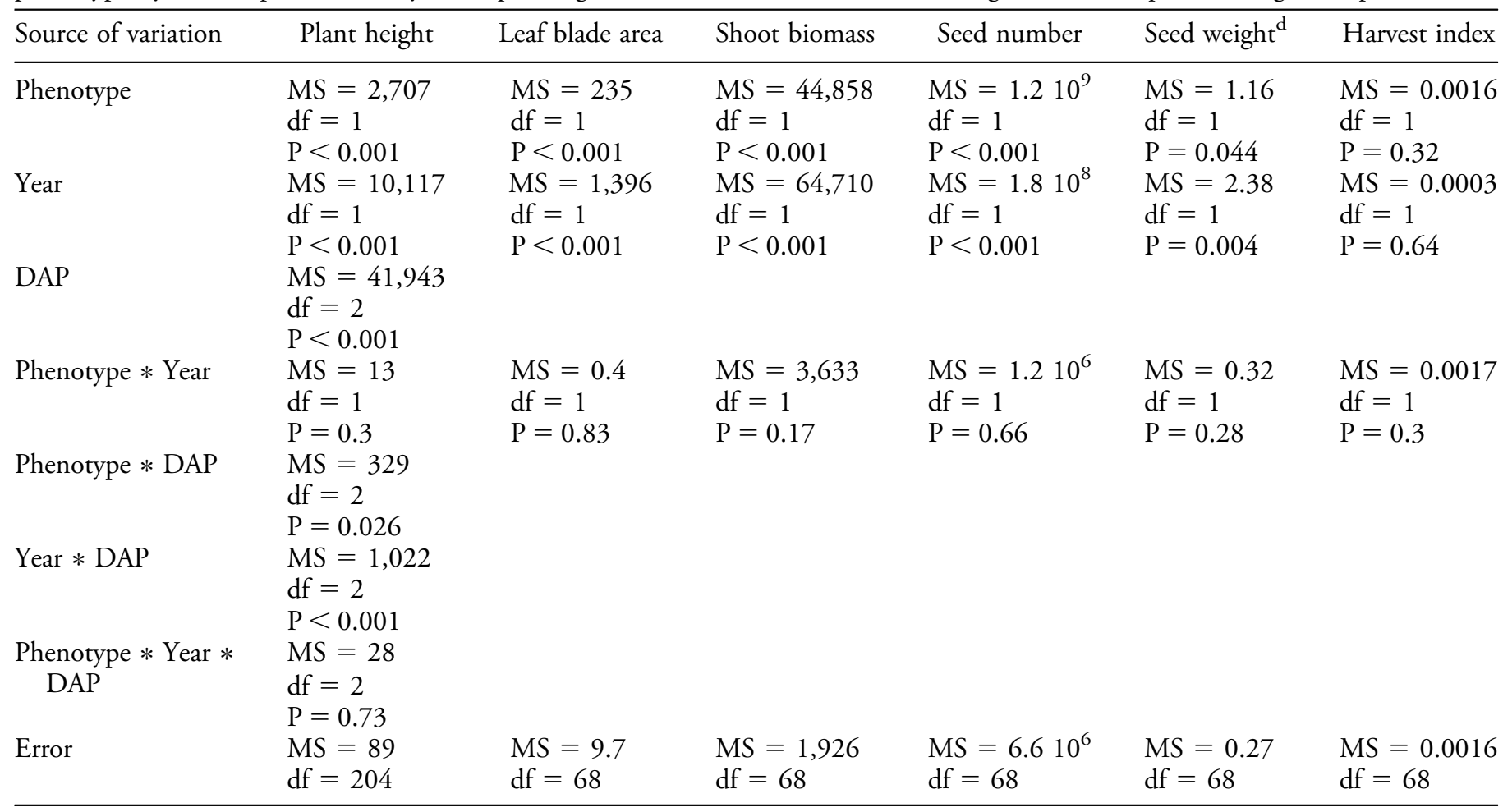

${ }^{a}$ Glyphosate-resistant and -susceptible phenotypes.

b 2011 and 2012 .

${ }^{\mathrm{c}} 60,120$, and 150 DAP.

${ }^{\mathrm{d}} n=1,000$. 


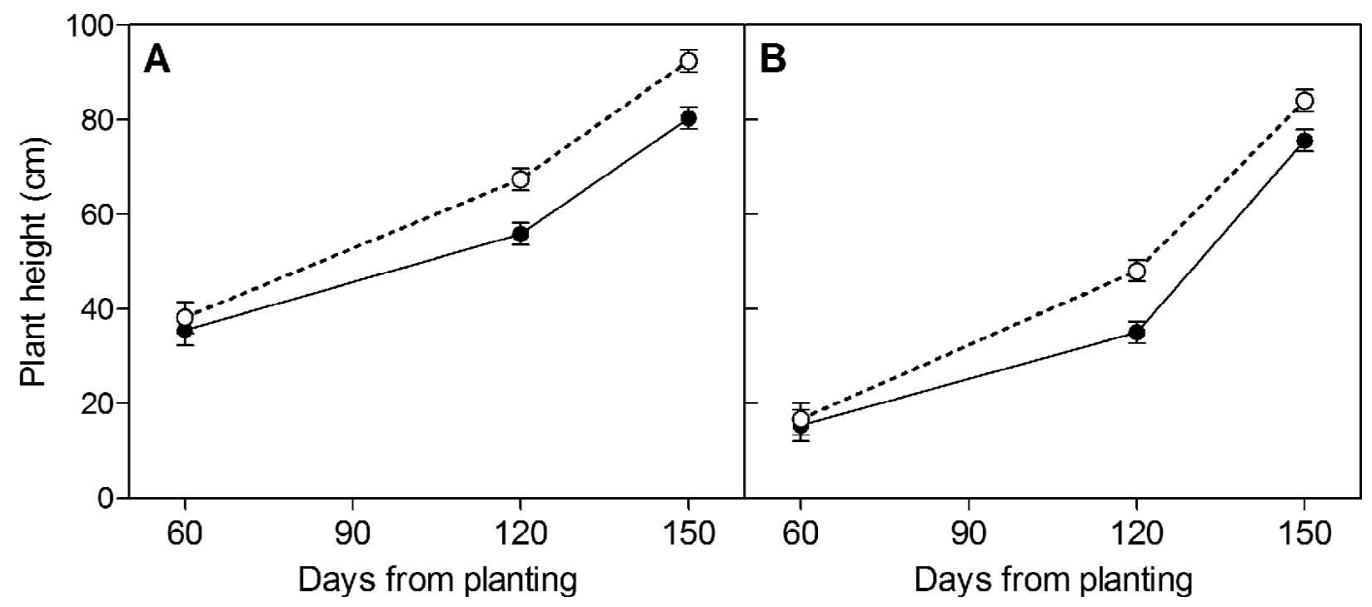

Figure 2. Plant height of glyphosate-resistant (•) and -susceptible (O) Perennial ryegrass phenotypes at 60, 120 , and $150 \mathrm{~d}$ after planting in (A) 2011 and (B) 2012. Values represent mean $(n=18)$ and vertical bars denote \pm 1 standard errors. Phenotype effect: P $<$ 0.001 (see Table 2).

shoot biomass $(\mathrm{P}<0.001)$, this was likely attributed to different water availability conditions. In the 2011 experiment, irrigation was used to complement rainfall, leading to about twice as much water availability, and shoot biomass production was twice that measured in 2012. Despite these differences in the amount of water available for plants between
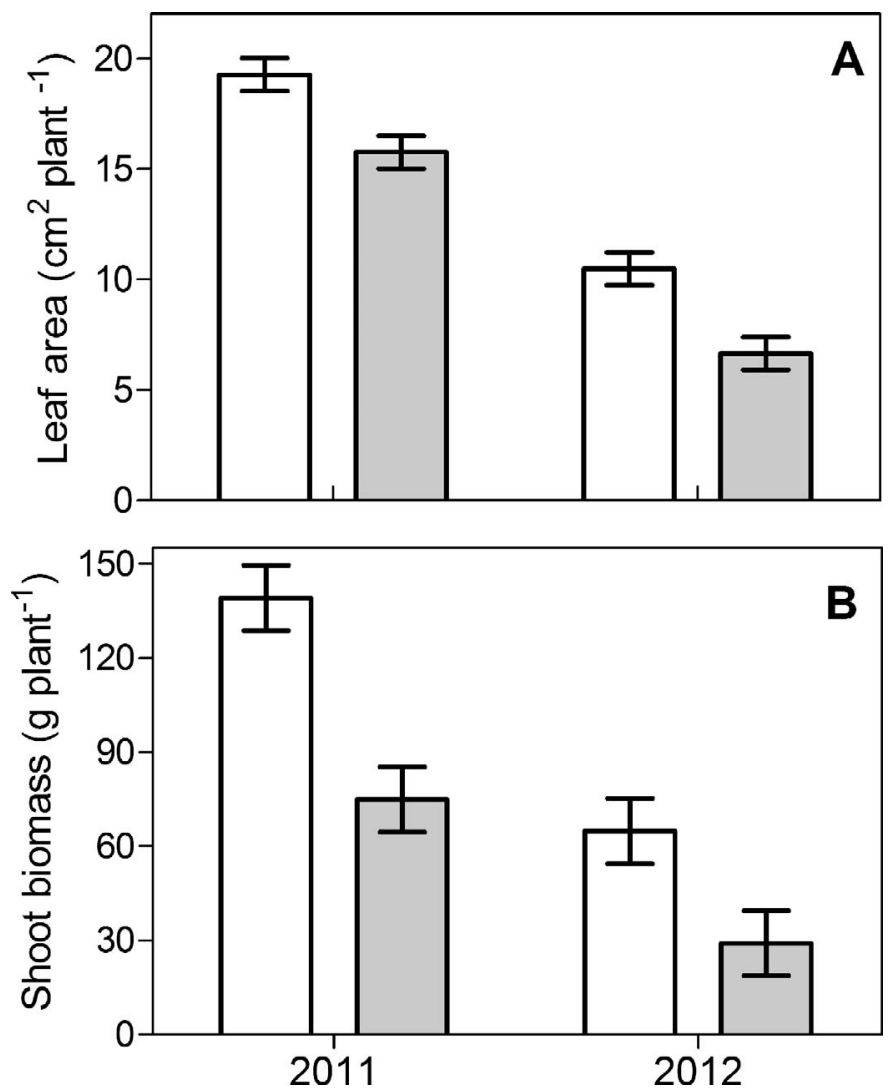

Figure 3. Leaf area (A) and total shoot biomass (B) produced per plant from glyphosate-resistant (gray bars) and -susceptible (white bars) Perennial ryegrass phenotypes in 2011 and 2012. Values are mean $(n=18)$ and vertical bars represent \pm 1 standard errors. Phenotype effect: $\mathrm{P}<0.001$ (see Table 2). experiments, the phenotype effect on shoot biomass persisted between years. Total shoot biomass produced by glyphosate-resistant plants was approximately one half of that of susceptible plants (Figure 3B).

The differences in plant height between both phenotypes were likely linked to the aerial plant biomass at maturity stage. However, the relative difference in total shoot biomass $(50 \%)$ was higher than the relative differences in height (14\%) and the leaf blade area $(24.5 \%)$. These size comparisons indicate that glyphosate-resistant plants were smaller than susceptible plants in all resource competition components (Goldberg 1990). Smaller plants usually show weaker competitive responses and effects on neighbor plants (Goldberg 1990).

Fitness Traits: Seed Yield Components. Glyphosate-resistant and -susceptible phenotypes showed differences in the number of spikes produced per plant $(P=0.005)$, spikelets per spike $(P=0.003)$, and seeds per spikelet $(P=0.03)$ (Figure 4). Glyphosateresistant plants had $25 \%$ fewer spikes, $10 \%$ fewer spikelets per spike, and fewer seeds per spikelet than glyphosate-susceptible plants (Figure 4). In 2011, regardless of the phenotype, seed production was approximately twofold higher than that in 2012 (Figure 5A). This, again, was likely due to the extra water availability in 2011 . Overall, glyphosate-resistant plants producing $40 \%$ less seed than glyphosatesusceptible plants in both years (Figure 5A).

The number of progeny is a key fecundity trait contributing to absolute fitness at the population level (Maynard Smith 1998; Vila-Aiub et al. $2009,2015 \mathrm{~b}$ ). The reduced seed production of glyphosate-resistant individuals was mainly due to reproductive tillers, spikelets per plant, and seeds 

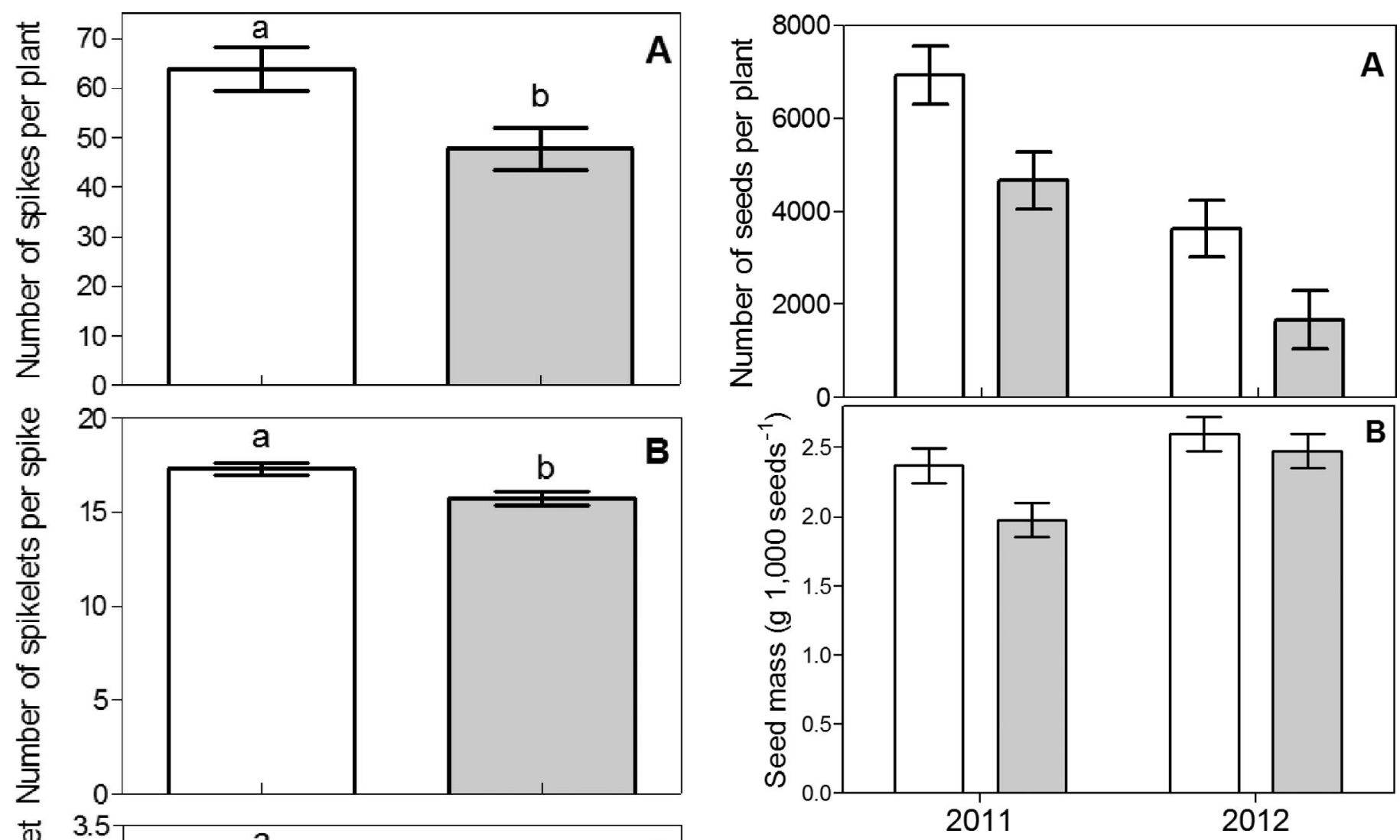

Figure 5. Seed number (A) and mass $(n=1,000)(\mathrm{B})$ estimated in glyphosate-resistant (gray bars) and -susceptible (white bars) perennial ryegrass plants in 2011 and 2012. Values are mean $(n=$ 18) and vertical bars represent \pm 1 standard error. Phenotype effects: (A) $\mathrm{P}<0.001$ and (B) $\mathrm{P}=0.044$ (see Table 2).

that of susceptible plants (Table 2, Figure 5B). Although the number and weight of seeds produced were different between susceptible and resistant plants, the ratio of seed weight to total plant weight was not significantly affected by the source of variations: phenotype, year nor phenotype * year interaction (Table 2), with a harvest index of $12.6 \%( \pm 0.4 \%$ standard error). Resource allocation to reproduction (i.e., harvest index) was similar between both glyphosate-resistant and -susceptible phenotypes highlighting that, whereas the smaller glyphosate-resistant plants showed lower reproductive output compared to the larger glyphosate-susceptible individuals, all plants maximized their reproductive output and relative allocation to reproduction was a constant trait across all sizes (Bonser and Aarssen 2009).

Provided that all other life-history traits remain similar, the observed differences in seed production between the glyphosate-resistant and -susceptible perennial ryegrass plants is likely to determine their persistence and frequency in populations in the absence of glyphosate selection (Vila-Aiub et al. 
2009). Therefore, it is likely a decline in the frequency of glyphosate-resistant individuals would occur once glyphosate selection is removed from the environment. Similarly, a reduction in the phenotypic level of glyphosate resistance over time has been observed in various perennial ryegrass populations (Preston et al. 2009). Although the specific perennial ryegrass fitness trait driving this glyphosate-resistance decline has not been determined, fitness costs in these populations likely originate from a resistance mechanism that impairs glyphosate translocation within the plants (Ge et al. 2012). It is clear that fitness costs associated with herbicide resistance are dependent on the particular resistance gene and mechanism selected in plants (Vila-Aiub et al. 2009). The fitness costs observed in our study are not associated with a target-site mutation in the EPSPS perennial ryegrass gene but a higher EPSPS activity (M. Yanniccari, unpublished observation). Recent evidence shows that constitutive amplification of the EPSPS gene resulting in up to 160 gene copy numbers in Palmer amaranth does not attract negative pleiotropic effects on plant growth and reproductive variables (Giacomini et al. 2014; VilaAiub et al. 2014). These results demonstrate that fitness costs associated with glyphosate resistance are not universal.

Fitness costs may be more evident when plants are growing under more extreme, stressful environmental conditions, although this prediction is not always true (Vila-Aiub et al. 2009). In the present study, the differential vegetative and reproductive traits observed between the glyphosate-resistant and -susceptible phenotypes were expressed in environments characterized by different soil water availability conditions. The fitness cost quantified in terms of seed number was 33 and 53\% in the 2011 and 2012 experiments, respectively. Considering that available water is an important factor determining seed yield, these findings reflect the stability of the fitness-cost expression in this glyphosate-resistant perennial ryegrass population.

Quantification of fitness costs associated with herbicide-resistance genes is helpful to parametrize herbicide-resistance modeling (Gressel and Segel 1990; Maxwell et al. 1990) and provide an evolutionary framework for answering fundamental questions about the cost of adaptation in plants (Vila-Aiub et al. 2009,2015 b). Further research is required to determine whether the fitness cost associated with glyphosate resistance in perennial ryegrass may be exploited in weed management strategies to prevent, delay, or reverse its evolution.

\section{Acknowledgments}

This research was partially supported by Consejo Nacional de Investigaciones Científicas y Técnicas (CONICET, National Research Council of Argentina) and Instituto Nacional de Tecnología Agropecuaria (INTA).

\section{Literature Cited}

Antonovics J, Thrall P (1994) The cost of resistance and the maintenance of genetic polymorphism in host-pathogen systems. Proc R Soc London Ser B 257:105-110

Ashigh J, Tardif F (2007) An $\mathrm{Ala}_{205}$ Val substitution in acetohydroxy-acid synthase of Eastern black nightshade (Solanum ptychanthum) reduces sensitivity to herbicides and feedback inhibition. Weed Sci 55:558-565

Baucom RS, Mauricio R (2004) Fitness costs and benefits of novel herbicide tolerance in a noxious weed. Proc Natl Acad Sci USA 101:13386-13390

Bonser SP, Aarssen LW (2009) Interpreting reproductive allometry: individual strategies of allocation explain size-dependent reproduction in plant populations. Perspect Plant Ecol 11: $31-40$

Charmet G, Balfourier F, Chatard V (1996) Taxonomic relationships and interspecific hybridization in the genus Lolium (grasses). Genet Resour Crop Evol 43:319-327

Duke SO, Powles SB (2008) Glyphosate: a once-in-a-century herbicide. Pest Manag Sci 325:319-325

Falster DS, Westoby M (2003) Plant height and evolutionary games. Trends Ecol Evol 18:337-343

Ge X, D’Avignon DA, Ackerman JJH, Collavo A, Sattin M, Ostrander EL, Hall EL, Sammons RD, Preston C. (2012) Vacuolar glyphosate-sequestration correlates with glyphosate resistance in ryegrass (Lolium spp.) from Australia, South America, and Europe: a 31P NMR investigation. J Agric Food Chem 60:1243-1250

Giacomini D, Westra P, Ward SM (2014) Impact of genetic background in fitness cost studies: an example from glyphosate-resistant palmer amaranth. Weed Sci 62:29-37

Goldberg DE (1990) Components of resource competition in plant communities. Pages 27-49 in Grace JB, Tilman, D, eds. Perspectives in Plant Competition. San Diego, CA: Academic Press

Grahan PL, Steiner JL, Wiese AF (1998) Light absorption and competition in mixed sorghum-pigweed communities. Agron J 80:415-418

Gressel J, Segel LA (1990) Modelling the effectiveness of herbicide rotations and mixtures as strategies to delay or preclude resistance. Weed Technol 4:186-198

Jasieniuk M, Brûlé-babel AL, Morrison IN (1996) The evolution and genetics of herbicide resistance in weeds. Weed Sci 44: 176-193

Jordan N, Kelrick M, Brooks J, Kinerk W (1999) Biorational management tactics to select against triazine-resistant Amaranthus hybridus: a field trial. J Appl Ecol 36:123-132

Lodovichi M, Yanniccari M (2015) Raigrás perenne (Lolium perenne) como maleza en Argentina. In Fernández O, Leguizamón E, Acciaresi H, eds. Malezas e Invasoras de la Argentina. Tomo III. Bahía Blanca: Edi UNS. In press 
Maxwell BD, Roush ML, Radosevich SR (1990) Predicting the evolution and dynamics of herbicide resistance in weed populations. Weed Technol 4:2-13

Maynard Smith J (1998) Evolutionary Genetics. Oxford, United Kingdom: Oxford Univerisity Press. 330 p

Menchari Y, Chauvel B, Darmency H, Delye C (2008) Fitness costs associated with three mutant acetyl-coenzyme A carboxylase alleles endowing herbicide resistance in black-grass Alopecurus myosuroides. J Appl Ecol 45:939-947

Pandey SK, Singh H (2011) A simple, cost-effective method for leaf area estimation. J Bot 2011:1-6

Paris M, Roux F, Berard A, Reboud X (2008) The effects of the genetic background on herbicide resistance fitness cost and its associated dominance in Arabidopsis thaliana. Heredity 101: 499-506

Pedersen BP, Neve P, Andreasen C, Powles S (2007) Ecological fitness of a glyphosate-resistant Lolium rigidum population: growth and seed production along a competition gradient. Basic Appl Ecol 8:258-268

Powles SB, Lorraine-Colwill DF, Dellow JJ (1998) Evolved resistance to glyphosate in rigid ryegrass (Lolium rigidum) in Australia. Weed Sci 46:604-607

Powles SB, Yu Q (2010) Evolution in action: plants resistant to herbicides. Annu Rev Plant Biol 61:317-347

Preston C, Powles S (2002) Evolution of herbicide resistance in weeds: initial frequency of target site-based resistance to acetolactate synthase-inhibiting herbicides in Lolium rigidum. Heredity 88:8-13

Preston C, Wakelin AM (2008) Resistance to glyphosate from altered herbicide translocation patterns. Pest Manag Sci 64: 372-376

Preston C, Wakelin AM, Dolman FC, Bostamam Y, Boutsalis P (2009) A decade of glyphosate-resistant Lolium around the world: mechanisms, genes, fitness, and agronomic management. Weed Sci 57:435-441

Roux F, Gasquez J, Reboud X (2004) The dominance of the herbicide resistance cost in several Arabidopsis thaliana mutant lines. Genetics 166:449-460

Salas R, Dayan F, Pan Z, Watson S, Dickson J, Scott R, Burgos N (2012) EPSPS gene amplification in glyphosate-resistant Italian ryegrass (Lolium perenne ssp. multiflorum) from Arkansas. Pest Manag Sci 68:1223-1230

Streibig JC, Rudemo M, Jensen JE (1993) Dose-response curves and statistical models. Pages 29-55 in Streibig JC, Kudsk P, eds. Herbicide Bioassays. Boca Raton: CRC Press

Tardif FJ, Rajcan I, Costea M (2006) A mutation in the herbicide target site acetohydroxyacid synthase produces morphological and structural alterations and reduces fitness in Amaranthus powellii. New Phytol 169:251-264

Vila-Aiub M, Goh S, Gaines T, Han H, Busi R, Yu Q, Powles S (2014) No fitness cost of glyphosate resistance endowed by massive EPSPS gene amplification in Amaranthus palmeri. Planta 239:793-801

Vila-Aiub MM, Gundel PE, Preston C (2015b) Experimental methods for estimation of plant fitness costs associated with herbicide-resistance genes. Weed Sci 63:203-216
Vila-Aiub MM, Neve P, Powles SB (2005a) Resistance cost of a cytochrome P450 herbicide metabolism mechanism but not an ACCase target site mutation in a multiple resistant Lolium rigidum population. New Phytol 167:787-796

Vila-Aiub MM, Neve P, Powles SB (2009) Fitness costs associated with evolved herbicide resistance alleles in plants. New Phytol 184:751-767

Vila-Aiub MM, Neve P, Roux F (2011) A unified approach to the estimation and interpretation of resistance costs in plants. Heredity 107:386-394

Vila-Aiub MM, Neve P, Steadman KJ, Powles SB (2005b) Ecological fitness of a multiple herbicide-resistant Lolium rigidum population: dynamics of seed germination and seedling emergence of resistant and susceptible phenotypes. J Appl Ecol 42:288-298

Vila-Aiub MM, Vidal AR, Balbi MC, Gundel PE, Trucco F, Ghersa CM (2008) Glyphosate-resistant weeds of South American cropping systems: an overview. Pest Manag Sci 64: 366-371

Vila-Aiub MM, Yu Q, Han H, Powles SB (2015) Effect of herbicide resistance endowing Ile-1781-Leu and Asp-2078-Gly ACCase gene mutations on ACCase kinetics and growth traits in Lolium rigidum. J Exp Bot. DOI: 10.1093/jxb/erv248

Yanniccari M, Istilart C, Giménez DO, Castro AM (2012a) Glyphosate resistance in perennial ryegrass (Lolium perenne L.) from Argentina. Crop Prot 32:12-16

Yanniccari M, Istilart C, Giménez DO, Castro AM (2015) Inheritance of glyphosate resistance in Lolium perenne and hybrids with Lolium multiflorum. Crop Prot 71:72-78

Yanniccari ME, Acciaresi HA (2013) Perennial weeds in Argentinean crop systems: biological and ecological characteristics and basis for a rational weed management. Pages 43-62 in Gorawala P, Mandhatri S, eds. Agricultural Research Updates. Vol. 5. New York, NY: Nova Science Publishers

Yanniccari ME, Istilart C, Giménez DO, Castro AM (2012b) Effects of glyphosate on the movement of assimilates of two Lolium perenne L. populations with differential herbicide sensitivity. Environ Exp Bot 82:14-19

Yanniccari ME, Tambussi E, Istilart C, Castro AM (2012c) Glyphosate effects on gas exchange and chlorophyll fluorescence responses of two Lolium perenne L. biotypes with differential herbicide sensitivity. Plant Physiol Biochem 57:210-217

Yu Q, Han H, Vila-Aiub MM, Powles SB (2010) AHAS herbicide resistance endowing mutations: effect on AHAS functionality and plant growth. J Exp Bot 61:3925-3934

Yu Q, Jalaludin A, Han H, Chen M, Sammons RD, Powles SB (2015) Evolution of a double amino acid substitution in the 5-enolpyruvylshikimate-3-phosphate synthase in Eleusine indica conferring high-level glyphosate resistance. Plant Physiol 167:1440-1447

Received April 17, 2015, and approved August 17, 2015.

Associate Editor for this paper: Chris Preston, University of Adelaide. 